\title{
The Need for a More Exact Analytical Characterization and Dosing of Cranberry Extract in Relation with its Actual Therapeutic Properties
}

Francesco Di Pierro*

Scientific Director of Velleja Research, Milan, Italy

\begin{abstract}
Vaccinium macrocarpon is characterized by the presence of type A proanthocyanidins (PACs) thought able, by interacting directly with type-P fimbrial structures found in uropathogenic strains, to prevent recurrent cystitis. According to clinical evidence the PAC dose needed seems to be $36 \mathrm{mg}$, when analyzed with a method called DMAC. Due to the use of different types of analytical method, most of European products whose labels read $36 \mathrm{mg}$ PACs/dose actually give values lower than stated, lacking of reproducibility. Moreover the "36 mg" issue, entericcoating, limiting the environmental oxidative stress over the PAC fraction of cranberry and avoiding the PACs to interact with gastric $\mathrm{H}$. pilori, optimizes efficacy of cranberry extract as demonstrated in clinical trials carried out in patients at risk for developing cystitis during pelvis radiotherapy, in patients with a diagnosis of recurrent cystitis and in patients with episodes of acute cystitis. In conclusion the real efficacy of a Vaccinium macrocarpon preparation can be assessed only after applying to the extract proper standardization and dosing procedures and taking into consideration the need of coating the finished product in order to protect PACs.
\end{abstract}

Keywords: Standardization phytochemical profile; Vaccinium macrocarpon

Abbreviation: PAC: Proanthocyanidins; UTI: Urinary Tract Infection; AFSSA: Agence Française de Sécurité Sanitaire des Aliments; DMAC: Dimethylaminocinnamaldehyde; UFC: Unit Forming Colony; EFSA: European Food Safety Authority

\section{Introduction}

'Medicines' are substances, or associations of substances, endowed with 'healing' or 'prophylactic' properties and capable of exerting actions of a pharmacological, immunological or metabolic nature. The same rule opposes medicine to the so-called 'medical devices' which, unlike the former, are healing and/or prophylactic tools working through a certain exclusively 'mechanical' quality of theirs. Until just a few years ago medicines and medical devices were the only instruments available to therapists, whether a physician, pharmacist or other.

More recently, Europe, as well as several non-European countries, witnessed a boom in the use of a third category of preparations: food supplements. They have been given the appellation of 'food' or 'dietary' because they actually belong to the food category and are defined as products intended to supplement the common diet. There are two types of them: those consisting of a concentrated source of nutritional substances (vitamins, minerals, amino acids, fatty acids) and those consisting of non-nutritional substances having a 'nutraceutic' value and physiological effects (fibers, vegetable extracts, probiotics, etc.) [1]. If the chemical, pharmacological and clinical handling of a product containing vitamins is not simple, it will be easy to imagine how much more difficult it will be to 'handle' a preparation containing derivatives extracted from medicinal plants. In fact, except for a few situations (just consider the case of Centella asiatica, containing 'only' 3 moleculesAsiatic acid, madecassic acid and asiaticoside in a 3:3:4 ratio) [2], the so-called standardized extracts contain hundreds, and in some cases thousands, of different molecules. Leaving out preparations classified according to the so-called extract-drug ratio and now ascribable to the 'phytotherapeutic prehistory', in less remote times researchers tried to overcome the difficulties of the chemical handling of these preparations by 'titrating' the preparation on the base of the presence of a given molecule (or a given fraction). The latter was quite frequently found to be nothing more than a chemical marker. As examples of the above, we may mention the cases of echinacoside or chicoric acid in Echinacea species, caffeic acids in the artichoke, harpagoside in the devil's claw and hypericin in St. John's wort. There are obviously many more cases like these.

\section{Standardization}

An alternative solution, which can cope with the difficult handling of an extract, is standardization. The latter-far from coinciding with titration-must be instead referred to the widest possible assortment of compounds that are typical of the phytochemical profile of a plant. Standardization guarantees constant composition, repeatability and efficacy. And in this case, more than ever, repeatability rhymes with scientificity [3]. The need for standardization of an extract-based preparation is also the more important the less the presence of a specific fraction can be related to a given therapeutic action. Just by way of example, it may be interesting to deal with two different types of extracts. While for some extracts it was impossible to relate the presence of a given fraction of components to a specific biological action, this was possible for other extracts.

An example of the first type is the Ginkgo biloba extract. When clinically validated, the extract is characterized by the presence of a flavonoid glucoside fraction (24\%) and a terpene fraction (6\%), but very little is known of the remaining $70 \%$ of the extract. The product is used as complementary treatment for cognitive impairment syndromes (for example, senile dementia, Alzheimer's disease), peripheral vascular disease (i.e., claudicatio intermittens, Raynaud's phenomenon) and, in

*Corresponding author: Francesco Di Pierro, Scientific Director of Velleja Research, Milan, Italy, E-mail: f.dipierro@vellejaresearch.com

Received February 18, 2013; Accepted March 08, 2013; Published March 11, 2013

Citation: Di Pierro F (2013) The Need for a More Exact Analytical Characterization and Dosing of Cranberry Extract in Relation with its Actual Therapeutic Properties. Altern Integ Med 2: 107. doi:10.4172/2327-5162.1000107

Copyright: (c) 2013 Di Pierro F. This is an open-access article distributed unde the terms of the Creative Commons Attribution License, which permits unrestricted use, distribution, and reproduction in any medium, provided the original author and source are credited. 
Citation: Di Pierro F (2013) The Need for a More Exact Analytical Characterization and Dosing of Cranberry Extract in Relation with its Actual Therapeutic Properties. Altern Integ Med 2: 107. doi:10.4172/2327-5162.1000107

the field of ophthalmology, diabetes-related retinal microangiopathy [4]. On the other hand, these actions have not been associated with a specific fraction. If, for example, the therapeutic action of the preparation in cognitive impairment could be related to the presence of the flavonoid glucoside fraction alone, it would be reasonable to use the latter as a pure substance and not only as a $24 \%$ component. In the same way, no correlation is known between the composition of devil's claw extracts and their anti-rheumatic activity [5]. If this correlation were found, the fraction could be purified, thus optimizing its activity profile.

On the other hand, there are also extracts whose 'compositionactivity' correlation has been well defined. Suffice it to think, for example, of Vitis vinifera derivatives, whose phlebotropic activity is closely related to the presence of 'procyanidolic oligomers' [6], or Boswellia serrata derivatives, whose action is well related to their titer in 'boswellic acids' [7].

\section{Vaccinium macrocarpon Extract}

Recently a preparation of this type, characterized by the presence of a single fraction capable of exerting the action of the whole extract, has actually invaded pharmacies and physician offices throughout Europe-Vaccinium macrocarpon (also called large cranberry, American cranberry and bearberry) extract. As is well known, the preparation is claimed to be a remedy against recurrent cystitis [8].

The plant monographs continue to mention the presence of such molecules as benzoic acid and fructose; the former can turn into hippuric acid and cause urine acidification with a consequent antibacterial effect, while the second can act directly on type 1 piliated, and therefore mannose-sensitive, E. coli strains. In spite of this, these two substances can hardly account for the effects yielded by the preparation in urology [9].

On the other hand, Vaccinium macrocarpon is characterized by the presence of polyphenolic structures (Figure 1)-the so-called type A proanthocyanidins (PACs)-and, on the contrary, their presence and characterization, in terms of administered doses, have been closely associated with its claimed activity against recurrent cystitis [10].

\section{PACs and their Activity against Recurrent Cystitis}

Recurrent cystitis, together with acute cystitis (also known as simple or incidental cystitis), interstitial cystitis, bacterial prostatitis and pyelonephritis, are ascribed to the UTI (Urinary Tract Infection) group. They are diseases caused by uropathogenic E. coli strains,
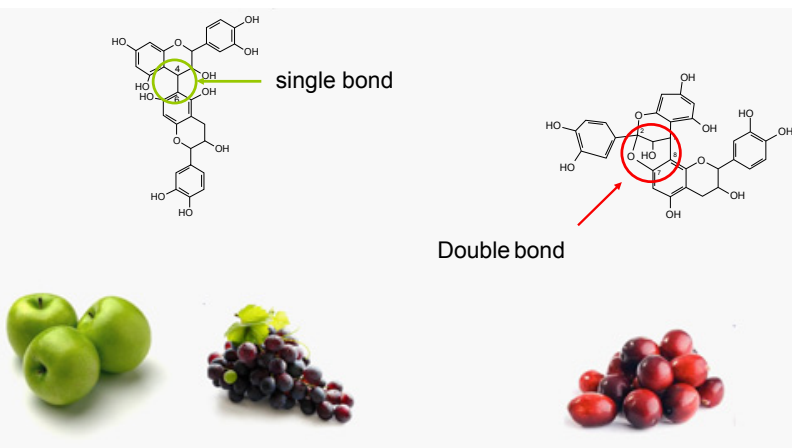

PAC B

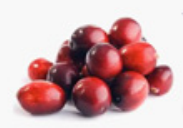

PAC A

Figure 1: Chemical structures of proanthocianidines type A (present only in macrocarpon fruit) and type B (present in fruits).

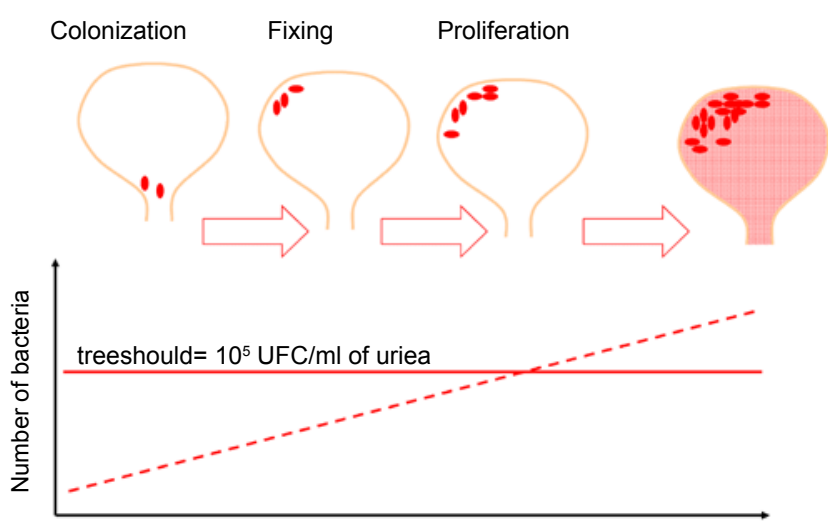

Figure 2: For UTI diagnosis of UTI a value of 100.000 bacteria per $\mathrm{ml}$ of urine is currently adopted.

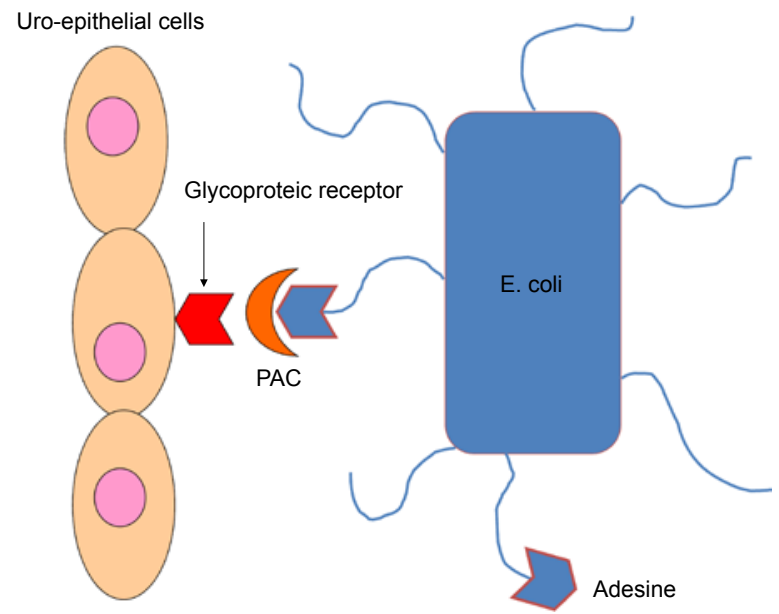

Figure 3: Role of PAC in blocking E. coli adesivity to uro-epithelial cells.

frequently of intestinal origin and capable of proliferating to such extent as to exceed the threshold of 100,000 bacteria per ml urine, thus leading to a diagnosis of cystitis (Figure 2). Like every other body organ subject to bacterial infections, the bladder would require an antibiotic therapy. As a matter of fact, as reported in many scientific works, use of Vaccinium macrocarpon derivatives containing PACs can combat this disorder with great efficacy. This treatment is obviously administered in patients with a negative urine-culture, which is expected, however, to turn positive again in the span of the subsequent 4 to 8 weeks. In fact, this event is called recurrence and is different from relapse, which is caused by the expansion of a residual bacterial clone not eliminated by the antibiotic treatment. In most cases it seems to be linked to bacterial transmigration-probably due to the anatomical proximity between the bowel and bladder-of bacteria capable of passing through the septa delimiting these two organs [11]. In this sense PACs, by interacting directly with type-P fimbrial structures found in uropathogenic $E$. coli strains, seem to prevent the fimbriae from binding to the receptor glycoprotein located on the urinary bladder epithelium. This hindrance apparently limits the ability of E. coli to adhere and, therefore, proliferate, so that the bacterium cannot any longer determine effective colonization and disease [12] (Figure 3).

\section{Recent History of Vaccinium macrocarpon}

Although the somewhat 'anti-bacterial' activity of the juice obtained 
by squeezing cranberry fruits has been known since 1923 [13], use of the juice as is recently decreased or was even discontinued, and extracts were obtained, first through production of products obtained from juice dehydration, and then through the usual extraction procedures. These extracts are variously capable of titrating $0.5,5,30$ and even $80 \%$ in PACs. Today the most widely used preparations are those titrated to $30 \%$, especially for their good quality/cost ratio. Just because of the fact that originally-when the PAC activity was still unknown-cranberry preparations 'were born' as juice, in recent years the question arose as to how the PAC quantity contained in the juice could be correlated to its clinical activity, so that an equivalent action could also be claimed for extracts. In 1994 Avorn et al. [14] published an excellent clinical work in JAMA, which answered this question at last. The answer is $36 \mathrm{mg}$. In fact, this is the quantity of PACs found in $300 \mathrm{~mL}$ cranberry juice, which demonstrated to be clinically effective in 153 elderly females suffering from recurrent cystitis. This work, whose data was then confirmed also by other authors, was submitted to the Agence Française de Sécurité Sanitaire des Aliments (AFSSA) to seek its official opinion on the potential activities of cranberry extracts. On some 3 occasions (2004, 2005 and 2007) AFSSA published a favorable opinion. The importance of this opinion is remarkable, as it was the first time that a physiological action, capable of affecting a disease positively, was officially associated in a direct manner to consumption of an edible fruit. The statement, translated into English, sounded as follows: the product helps reduce the adhesion of certain uropathogenic E.coli bacteria to the urinary tract walls. In the same document AFSSA stated that the activity was closely linked to the presence of at least $36 \mathrm{mg}$ PACs. They forgot, however, to mention the method used to measure PACs.

\section{Different Method, Different Concentration}

Analysis of PACs had been performed using a validated and sensitive method known as DMAC. This colorimetric method, which makes use of Dimethylaminocinnamaldehyde as the specific reagent, had been developed by a U.S. company, Ocean Spray (Lakeville-Middleboro, MA 02349 U.S.A.). There were, however, at least another three PAC analysis methods in cranberry derivatives: the HPLC method, the method used by the European Pharmacopeia and the Bates-Smith method. Each different method yielded a different analytical reading. Consequently, a cranberry sample that will show the presence of $36.4 \mathrm{mg}$ PACs when analyzed using the DMAC method, will read 67.1, 89.2 and $187.2 \mathrm{mg}$ respectively when the three above methods are used (Figure 4).

As shown in figure 5, European products whose labels read $36 \mathrm{mg}$

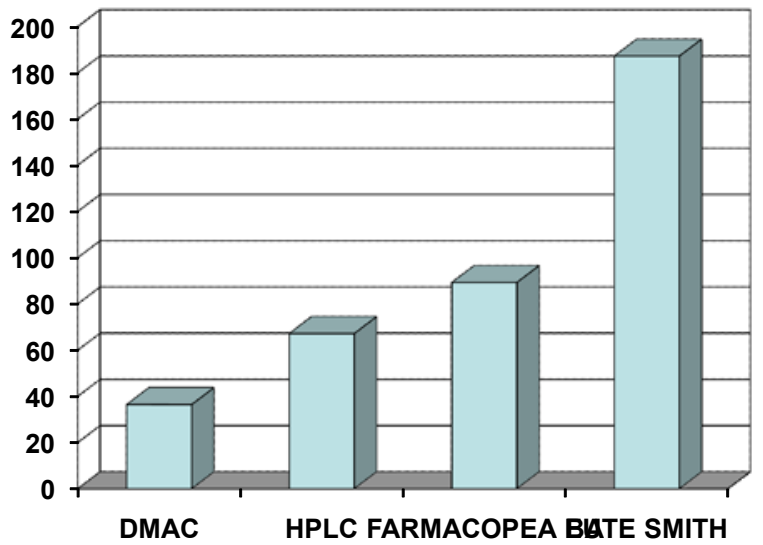

Figure 4: Relationship between method and PAC content.

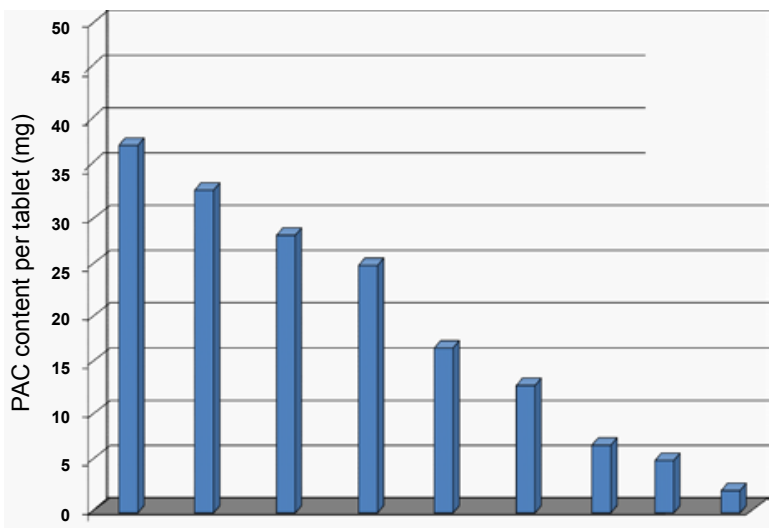

Figure 5: PAC content, according to the DMAC method, in some European products containing cranberry extract.

PACs/dose actually give quite different values-lower than stated-if they are analyzed using the DMAC method. And this problem regards all European countries, including Italy. As a matter of fact, it is not a question of willful preparation counterfeiting. Nor is it a problem with legal implications. All the statements on the labels refer to results obtained using a method validated and recognized by the European Pharmacopeia. The declarations are not false. They are simply inappropriate from a scientific point of view.

Although a dietary supplement is not expected to treat a disease, but only facilitate the physiology of a natural recovery, cranberry can do this only at a daily dose of $36 \mathrm{mg}$, measured through DMAC analysis. Use of other analysis methods will give oversized values and make the preparation ineffective. The preparations were most likely developed in complete 'good faith' by their formulators, and the mistake is only of a cognitive nature.

It seems obvious, after the above observations, that any scientific/ regulatory body (for example, EFSA) can express an opinion on any claim attributable to a phytotherapeutic preparation, only after considering not only the extract nature, standardization and titration, but also the analytical method applied to define the active ingredient concentration linked to its clinical efficacy.

\section{Cranberry and PAC Dosing: A Problem that may be Solved}

Apart from the analytical problems discussed so far, it should be noted that the question of the cranberry activity appears to be resolvable without resorting necessarily to the analytical possibility offered by the DMAC method. If one can use a highly standardized product, which is repeatable in chemical terms in its molecular $100 \%$, it will be possible to draw a simple dose-response curve; this assay is usually performed in the testing of any drug, but is seldom used in phytotherapy. In this case the curve was applied to a standardized extract titrated to $30 \%$ in PACs (European Pharmacopeia method), and this made it possible to highlight a dose-dependent activity. The latter occurs, in a statistically significant manner, with $400 \mathrm{mg} /$ day of product [15]. When considering the ratio (3:1) obtained by assessing a cranberry-based product with the European Pharmacopeia method and DMAC method, it can be seen that $400 \mathrm{mg}$ at $30 \%$, with $120 \mathrm{mg}$ PACs being claimed, actually contain 3 times less the claimed value, that is, $40 \mathrm{mg}$, and the latter value closely approximates the $36 \mathrm{mg}$ mentioned by Avorn et al. [14] and AFSSA. 
Citation: Di Pierro F (2013) The Need for a More Exact Analytical Characterization and Dosing of Cranberry Extract in Relation with its Actual Therapeutic Properties. Altern Integ Med 2: 107. doi:10.4172/2327-5162.1000107

Page 4 of 5

\section{The Next Step: Proper Use of Pharmaceutical Compounding Techniques}

The story of the cranberry does not end here, because there are at least two other things to consider. PACs are polyphenolic structures with marked antioxidant properties. Like all antioxidants, PACs are rather unstable, and any industrial or formulative management ignoring this characteristic will tend to reduce their quantity [16]. Finally, it should not be forgotten that PACs are capable of also interacting with such typical stomach-colonizing bacteria as $H$. pylori [16]. The possible presence of the latter bacterium in the stomach of a patient obviously reduces the quantity of PACs available to oppose the action of E. coli. These problems can be solved by formulating PACs as gastroprotected tablets. Gastroprotection prevents disaggregation of active ingredients in the stomach and allows them to be released only when the environmental $\mathrm{pH}$ is around 6.0-6.8, a typical value of the duodenum. Gastroprotection also minimizes the PAC loss linked to their bond with prolin-rich proteins (like those found in saliva) and biological membranes of parts of the alimentary canal (like the stomach) where they are not absorbed significantly.

\section{Clinical Assessment of Gastroprotected Forms of Vaccinium macrocarpon}

The hypothesis that gastroprotection (Patent Application WO2012/123491) of a formulation containing Vaccinium macrocarpon extract titrated to $30 \%$ in PACs would optimize its pharmacoclinical yield was submitted to clinical verification at the Oncological Radiotherapy Department of Cremona Hospital, where it was tested in 370 patients at risk for developing cystitis during pelvis radiotherapy. Administered in doses of $200 \mathrm{mg} /$ day (corresponding to $50 \%$ of the dose used to administer at least $36 \mathrm{mg}$ PACs), it reduced cystitis incidence by about $2 / 3$ in comparison with untreated controls [17]. On a previous occasion, the same preparation had already demonstrated its efficacy in preventing recurrent cystitis with an over $90 \%$ protection at $200 \mathrm{mg} /$ day, while administration of $400 \mathrm{mg}$ increased protection to 100\% [18].

\section{Treatment of Acute Cystitis}

The observation of a correlation among pharmaceutical form, administered dose and demonstrated clinical effect also led some investigators (ASL 1, Rome) to test the preparation in different doses in episodes of acute cystitis. In fact, cranberry-based preparations are traditionally administered in patients exhibiting monthly or twomonthly recurrent episodes, at a time when no symptoms are present and the urine culture is negative. It had been observed in the previous clinical trial that the product administration prevented recurrence of the disorder. It was thus decided to verify the action of the gastroprotected product in acute cystitis by enrolling feverless patients, with light symptoms (dysuria, nycturia, urinary urgency, etc.) and a positive urine culture ( $>100.000 \mathrm{UFC} / \mathrm{mL}$ ). The patients were subdivided into 3 treatment groups: $600 \mathrm{mg} /$ day in the evenings $(180 \mathrm{mg}$ PAC according to the Pharmacopeia and $60 \mathrm{mg}$ according to DMAC), $600 \mathrm{mg}$ every 12 hours, and 1,200 $\mathrm{mg}$ /day in the evenings ( $360 \mathrm{mg}$ PAC according to the Pharmacopeia and $120 \mathrm{mg}$ according to DMAC). Treatment of all the 3 groups continued for 5 days. Urine cultures were performed on enrolment, after 5 treatment days and then after 5 day wash-out $(t=10)$.

Tables 1-3 show the microbial charge trend and tolerability of each individual patient. These results-still preliminary and being re-assessed in a controlled hospital trial-show an evident dose-dependent response and suggest that a dose of $120 \mathrm{mg}$ PACs (evaluated through the DMAC method) may be a potential valid alternative to antibiotic treatment,

\begin{tabular}{|c|c|c|c|c|c|}
\hline Pat & $\mathbf{S}$ & $t=0$ & $t=5$ & $t=10$ & $T$ \\
\hline FM & $\mathrm{F}$ & $\begin{array}{c}\text { Enterococcus } \\
>100.000\end{array}$ & $\begin{array}{c}\text { E.coli } \\
<50.000\end{array}$ & $\begin{array}{c}\text { E.coli } \\
<50.000\end{array}$ & G \\
\hline GD & $\mathrm{F}$ & $\begin{array}{c}\text { E.coli } \\
>100.000\end{array}$ & $\begin{array}{l}\text { E. coli } \\
<50.000\end{array}$ & Sterile & $E$ \\
\hline GB & $\mathrm{F}$ & $\begin{array}{l}\text { Proteus } \\
>100.000\end{array}$ & $\begin{array}{l}\text { E. coli } \\
<50.000\end{array}$ & $\begin{array}{c}\text { E.coli } \\
<50.000\end{array}$ & $E$ \\
\hline LP & $\mathrm{F}$ & $\begin{array}{l}\text { Klebsiella } \\
>100.000\end{array}$ & $\begin{array}{c}\text { Enterococcus } \\
>100.000\end{array}$ & $\begin{array}{c}\text { E. coli } \\
<50.000\end{array}$ & $E$ \\
\hline FP & M & $\begin{array}{c}\text { E. coli } \\
>100.000\end{array}$ & Sterile & Sterile & $E$ \\
\hline PS & $\mathrm{F}$ & $\begin{array}{l}\text { Candida } \\
>100.000\end{array}$ & $\begin{array}{c}\text { E. coli } \\
>100.000\end{array}$ & Sterile & $E$ \\
\hline GS & M & $\begin{array}{c}\text { Enterococcus } \\
>100.000\end{array}$ & $\begin{array}{l}\text { Enterococcus } \\
\quad<50.000\end{array}$ & $\begin{array}{l}\text { E. coli } \\
<50.000\end{array}$ & $E$ \\
\hline
\end{tabular}

Pat =patient; S=sex; T= tolerability; G=good; E=Excellent

Table 1: Trend (UFC/mL) in patients with a diagnosis of acute cystitis, treated for 5 days with $600 \mathrm{mg}$ gastroprotected preparation.

\begin{tabular}{|c|c|c|c|c|c|}
\hline Pat & $\mathbf{S}$ & $\mathbf{t}=\mathbf{0}$ & $\mathbf{t}=\mathbf{5}$ & $\mathbf{t = 1 0}$ & $\mathbf{T}$ \\
\hline VF & $\mathrm{M}$ & $\begin{array}{c}\text { E. coli } \\
>100.000\end{array}$ & Sterile & Sterile & $\mathrm{E}$ \\
\hline $\mathrm{DW}$ & $\mathrm{F}$ & $\begin{array}{c}\text { Klebsiella } \\
>100.000\end{array}$ & $\begin{array}{c}\text { E. coli } \\
>100.000\end{array}$ & Sterile & $\mathrm{E}$ \\
\hline $\mathrm{RP}$ & $\mathrm{F}$ & $\begin{array}{c}\text { Enterococcus } \\
>100.000\end{array}$ & $\begin{array}{c}\text { E. coli } \\
>100.000\end{array}$ & $\begin{array}{c}\text { E.coli } \\
>100.000\end{array}$ & $\mathrm{G}$ \\
\hline $\mathrm{GS}$ & $\mathrm{F}$ & $\begin{array}{c}\text { Candida } \\
>100.000\end{array}$ & $\begin{array}{c}\text { E. coli } \\
>100.000\end{array}$ & Sterile & $\mathrm{E}$ \\
\hline $\mathrm{RP}$ & $\mathrm{M}$ & $\begin{array}{c}\text { Proteus } \\
>100.000\end{array}$ & $\begin{array}{c}\text { E. coli } \\
<50.000\end{array}$ & Sterile & $\mathrm{E}$ \\
\hline $\mathrm{PG}$ & $\mathrm{M}$ & $\begin{array}{c}\text { Candida } \\
>100.000\end{array}$ & $\begin{array}{c}\text { Candida } \\
<50.000\end{array}$ & $\begin{array}{c}\text { E. coli } \\
<50.000\end{array}$ & $\mathrm{G}$ \\
\hline $\mathrm{RP}$ & $\mathrm{F}$ & $\begin{array}{c}\text { E. coli } \\
>100.000\end{array}$ & $\begin{array}{c}\text { E. coli } \\
<50.000\end{array}$ & Sterile & $\mathrm{E}$ \\
\hline $\mathrm{LG}$ & $\mathrm{F}$ & $\begin{array}{c}\text { Enterococcus } \\
>100.000\end{array}$ & Sterile & Sterile & $\mathrm{E}$ \\
\hline
\end{tabular}

Pat=patient; S=sex; T=tolerability; G=good; E=Excellent

Table 2: Trend (UFC/mL) in patients with a diagnosis of acute cystitis, treated for 5 days with $600 \mathrm{mg}$ gastroprotected preparation every 12 hours.

at least with regard to well controlled situations (no fever and light symptoms).

\section{Conclusions}

Vaccinium macrocarpon extract is undoubtedly a product that well complements the available medical tools in treatment of recurrent cystitis from fimbriated bacteria. Its action is strongly linked to the presence of PACs. Their presence in quantities of at least $36 \mathrm{mg}$ is potentially a guarantee of success. The analytical method must be followed carefully, and the resulting levels have to be re-parameterized depending on the method used.

The extracts usually titrated according to the European Pharmacopeia method to have a $30 \%$ content in PACs exhibit their clinical action starting from the dose of $400 \mathrm{mg} /$ day extract. The extracts titrated to $30 \%$ according to the European Pharmacopeia method and made gastroprotected with the use of food-grade, filmforming substances exhibit their clinical action starting from the dose of $200 \mathrm{mg} /$ day, while a $400 \mathrm{mg}$ /day dose offers a protection approaching $100 \%$ of the cases (in prevention of recurrent cystitis). Administration of $1200 \mathrm{mg}$ /day gastroprotected product provides good clinical efficacy also in treatment of acute cystitis.

The real efficacy of a Vaccinium macrocarpon preparation will be better defined only by paying great attention to the analytical method 
Citation: Di Pierro F (2013) The Need for a More Exact Analytical Characterization and Dosing of Cranberry Extract in Relation with its Actual Therapeutic Properties. Altern Integ Med 2: 107. doi:10.4172/2327-5162.1000107

Page 5 of 5

\begin{tabular}{|c|c|c|c|c|c|}
\hline Pat & $S$ & $t=0$ & $t=5$ & $t=10$ & $\mathrm{~T}$ \\
\hline GM & $M$ & $\begin{array}{c}\text { Enterococcus } \\
>100.000\end{array}$ & Sterile & Sterile & G \\
\hline $\mathrm{FP}$ & $M$ & $\begin{array}{c}\text { E. coli } \\
>100.000\end{array}$ & Sterile & Sterile & G \\
\hline GB & $\mathrm{F}$ & $\begin{array}{c}\text { Candida } \\
>100.000\end{array}$ & $\begin{array}{l}\text { Candida } \\
<50.000\end{array}$ & $\begin{array}{c}\text { E.coli } \\
<50.000\end{array}$ & G \\
\hline MM & $M$ & $\begin{array}{c}\text { E. coli } \\
>100.000\end{array}$ & $\begin{array}{l}\text { E. coli } \\
<50.000\end{array}$ & Sterile & G \\
\hline MJ & $\mathrm{F}$ & $\begin{array}{c}\text { Enterococcus } \\
>100.000\end{array}$ & Sterile & Sterile & $E$ \\
\hline LC & $\mathrm{F}$ & $\begin{array}{c}\text { Candida } \\
>100.000\end{array}$ & $\begin{array}{l}\text { Candida } \\
<50.000\end{array}$ & $\begin{array}{l}\text { E. coli } \\
<50.000\end{array}$ & G \\
\hline $\mathrm{SL}$ & $F$ & $\begin{array}{c}\text { E. coli } \\
>100.000\end{array}$ & Sterile & Sterile & $E$ \\
\hline PS & $\mathrm{F}$ & $\begin{array}{c}\text { E. coli } \\
>100.000\end{array}$ & Sterile & Sterile & G \\
\hline $\mathrm{RP}$ & $\mathrm{F}$ & $\begin{array}{c}\text { Enterococcus } \\
>100.000\end{array}$ & $\begin{array}{c}\text { E. coli } \\
<50.000\end{array}$ & Sterile & G \\
\hline MM & $M$ & $\begin{array}{c}\text { Candida } \\
>100.000\end{array}$ & $\begin{array}{l}\text { Candida } \\
<50.000\end{array}$ & Sterile & $E$ \\
\hline RT & $\mathrm{F}$ & $\begin{array}{l}\text { Candida } \\
>100.000\end{array}$ & $\begin{array}{l}\text { E. coli } \\
<50.000\end{array}$ & Sterile & G \\
\hline MF & $\mathrm{F}$ & $\begin{array}{c}\text { E. coli } \\
>100.000\end{array}$ & $\begin{array}{c}\text { E. coli } \\
<50.000\end{array}$ & Sterile & G \\
\hline MR & $F$ & $\begin{array}{c}\text { Enterococcus } \\
>100.000\end{array}$ & $\begin{array}{c}\text { E. coli } \\
<50.000\end{array}$ & Sterile & $E$ \\
\hline AR & $F$ & $\begin{array}{c}\text { E. coli } \\
>100.000\end{array}$ & Sterile & Sterile & G \\
\hline GT & $F$ & $\begin{array}{c}\text { E. coli } \\
>100.000\end{array}$ & Sterile & Sterile & G \\
\hline
\end{tabular}

6. Iriti M, Faoro F (2009) Bioactivity of grape chemicals for human health. Nat Prod Commun 4: 611-634.

7. Sharma A, Gupta NK, Dixit VK (2010) Complexation with phosphatidyl choline as a strategy for absorption enhancement of boswellic acid. Drug Deliv 17: 587-595.

8. Guay DR (2009) Cranberry and urinary tract infections. Drugs 69: 775-807.

9. Pappas E, Schaich KM (2009) Phytochemicals of cranberries and cranberry products: characterization, potential health effects, and processing stability. Crit Rev Food Sci Nutr 49: 741-781.

10. Howell AB, Botto H, Combescure C, Blanc-Potard AB, Gausa L, et al. (2010) Dosage effect on uropathogenic Escherichia coli anti-adhesion activity in urine following consumption of cranberry powder standardized for proanthocyanidin content: a multicentric randomized double blind study. BMC Infect Dis 14: 1094.

11. Rossi R, Porta S, Canovi B (2010) Overview on cranberry and urinary tract infections in females. J Clin Gastroenterol 44: S61-62.

12. Pinzón-Arango PA, Liu Y, Camesano TA (2009) Role of cranberry on bacterial adhesion forces and implications for Escherichia coli-uroepithelial cell attachment. J Med Food 12: 259-270.

13. Blatherwick J (1923) Vaccinium macrocarpon J Biol Chem 57: 815-818.

14. Avorn J, Monane M, Gurwitz JH, Glynn RJ, Choodnovskiy I, et al. (1994) Reduction of bacteriuria and pyuria after ingestion of cranberry juice. JAMA 271: 751-754.

15. Bailey DT, Dalton C, Joseph Daugherty F, Tempesta MS (2007) Can a concentrated cranberry extract prevent recurrent urinary tract infections in women? A pilot study. Phytomedicine 14: 237-241.

16. Matsushima M, Suzuki T, Masui A, Kasai K, Kouchi T, et al. (2008) Growth inhibitory action of cranberry on Helicobacter pylori. J Gastroenterol Hepatol 23: S175-180.

17. Bonetta A, Di Pierro F (2012) Enteric-coated, highly standardized cranberry extract reduces risk of UTIs and urinary symptoms during radiotherapy for prostate carcinoma. Cancer Manag Res 4: 281-286.

Table 3: Trend (UFC/mL) in patients with a diagnosis of acute cystitis, treated for 5 days with $1,200 \mathrm{mg}$ gastroprotected preparation.

used to determine the actual correlation between the presence of PACs and the activity. Without this determination, the action of a preparation, however standardized it may be, can be claimed only after a clinical assessment that takes account of a dose-effect curve.

A trial versus an antibiotic therapy in treatment of acute cystitis (protocol approved by the local Ethical Committee) is presently being conducted in a hospital, and the results will be the subject of future assessments and interpretations also in the light of earlier results.

\section{References}

1. www.salute.gov.it

2. Gao M, Yuan X, Xiao H (2008) Preparation of asiaticoside and madecassoside from the extract of Centella asiatica (L.) Urb using preparative high performance liquid chromatography. Se Pu 26: 362-365.

3. Shan JJ, Rodgers K, Lai CT, Sutherland SK (2007) Challenges in natural health product research: The importance of standardization. Proc West Pharmacol Soc 50: $24-30$.

4. Weinmann S, Roll S, Schwarzbach C, Vauth C, Willich SN (2010) Effects of Ginkgo biloba in dementia: systematic review and meta-analysis. BMC Geriatr 10: 14

5. (2008) Harpagophytum procumbens (devil's claw). Monograph. Altern Med Rev 13: $248-252$

18. Di Pierro F, Bonetta A, Rapacioli G (2009) Use of a highly standardized extract of Vaccinium macrocarpon and gastroprotetto. Clinical efficacy in bladder infections Int Nutr 12: 19-23. 